\title{
Husband's Support in the Taking-hold Phase of Postpartum (Phenomenology Study)
}

\author{
Elsye Maria Rosa ${ }^{1 *}$, Popy Apriyanti ${ }^{2}$, Dhesi Ari Astuti ${ }^{2}$ \\ ${ }^{1}$ Department of Public Health, Master of Hospital Administration, Universitas Muhammadiyah Yogyakarta, Bantul, Indonesia; \\ ${ }^{2}$ Department of Midwifery, Masters of Midwifery, University of Aisyiyah Yogyakarta, Sleman, Indonesia
}

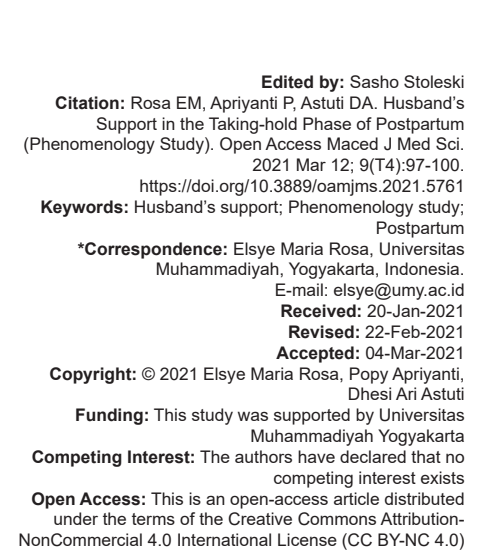

Abstract

BACKGROUND: The puerperium is a period that begins after the birth of the placenta and ends when the uterus organs return to their pre-pregnancy state, which lasts for about 6 weeks or after delivery until 42 days of delivery. This period is a crucial period for mothers and newborns because, at this time, mothers are required to adapt to their new role of being a mother.

AIM: This study aims to explore the husband's support in the taking-hold phase of postpartum primigravida cesarean section and normal labor.

METHODS: This study used a qualitative research design employing a phenomenological approach. The purposive sampling method was utilized in selecting 10 informants. Data analysis used a Colaizzi analysis and Nvivo 12 Plus software.

RESULTS: The results showed that the husband's support influenced postpartum mothers in the (1) emotional changes, (2) baby care, (3) wound care, and (4) nutritional fulfillment.

CONCLUSION: The husband's support in the taking-hold postpartum phase was proven to deal with psychological adaptation and help postpartum maternal health care.

\section{Introduction}

The puerperium begins after the placenta's birth and ends when the uterus organs return to their pre-pregnancy state, which lasts for about 6 weeks or after delivery until 42 days of delivery. This period is a crucial period for mothers and newborns. At this time, mothers are required to adapt to their new role [1].

During the puerperium, mothers experience many essential events, ranging from physiological changes to psychological changes in facing a new family with a baby who needs attention and affection. At this time, postpartum mothers become sensitive so that the role of health workers (doctors, midwives, and nurses) is vital in explaining the mother's condition and psychological approaches to avoid pathological psychological changes. The support and attention of family members, especially husbands, provide positive support for postpartum mothers. Postpartum mothers undergo adaptation through the following phases: The taking-in phase, the taking-hold phase, and the letting-go phase. Postpartum mothers' psychological phase can be experienced in mothers with normal postpartum and postpartum cesarean section. The method of childbirth experienced by mothers can affect their postpartum psychological adaptation [2].

Factors that influence postpartum mothers are internal factors (coming from within the mother herself), external factors that comprise cultural factors, and environmental factors, including health workers and families. Of these factors, the role of the family is the main factor that triggers postpartum disorders. From several studies, it was found that the risk of mothers experiencing postpartum disorders would increase without any support from their family [3].

The most important support is the family's role, in which the family is two or more individuals living in one household because of blood relations, marriage, or adoption. One of the roles of the family is to maintain the mother's health after childbirth by giving love to the mother after giving birth so that the mother feels cared for, delivering for control, encouraging to eat nutritious food, allowing adequate rest, maintaining personal hygiene, and helping to care for the baby (BKKBN, 2014).

Husbands have a vital role in maternal health and safe delivery. Husband's involvement needs to be recognized and addressed in health education because of the potential benefits to maternal and child health outcomes [4]. 
In this study, the researchers would like to know how the husband's support works for postpartum mothers. In managing psychological adaptation, it is inseparable from the supportive husband's role so that postpartum mothers can handle changes optimally.

\section{Methods}

This study used a qualitative research design based on the research objectives, employing a phenomenological approach [5]. This study's population was normal primigravida postpartum mothers and postpartum cesarean section and husbands living in the same house. Determination of samples taken was samples that met the inclusion criteria: Normal primigravida postpartum mothers, primigravida postpartum cesarean section mothers, and the husbands who lived in the same house with their wives.

In-depth interviews carried out data collection. Interviews were conducted at RSKIA Sadewa, a development of the SEMAR Medical Center, Maternity Hospital, Maternal and Child Health (BP-RB-KIA SEMAR), and are under the Prima Semar Health Service Foundation. The questions were divided into three groups, namely, emotional support, instrument support, and information support. These questions were asked to postpartum mothers and husbands who agreed to be subjects or respondents in this study.

The interview results are in the form of descriptive explanations so that the answers to the formulation of research problems are more apparent. The documentary studies used in field research are divided into two: Primary and secondary documents. The main documents in the study are the results of field notes, audio, and visual materials, while secondary documents are medical recordings carried out by hospital staff from the time the informant arrived at the hospital until after delivery.

Data analysis used Colaizzi analysis and Nvivo 12 Plus software. Data from the interview method, documentation, and data triangulation were processed together in one analysis process based on the data analysis step.

\section{Results and Discussion}

From Table 1, there are five husband informants in this study. The age of the informants was between 23 and 40 years. The informants' last education varies; one informant is an undergraduate, and four informants are senior high school graduates. Many informants
Table 1: Husband's characteristics

\begin{tabular}{lllll}
\hline No. & Age & Last education & Profession & Length of marriage \\
\hline 1 & 23 & Senior high school & Entrepreneur & 1 year \\
2 & 29 & Undergraduate & Private employees & 1 year \\
3 & 29 & Senior high school & Entrepreneur & 1 year \\
4 & 30 & Senior high school & Private employees & 3 years \\
5 & 40 & Senior high school & TNI AU (Air Force) & 8 years \\
\hline
\end{tabular}

work as private employees. One informant is in the Air Force, and two informants are entrepreneurs. The characteristics of the informants' length of the marriage vary. Three informants have married for 1 year, one informant for 3 years, and another informant has married for 8 years.

Based on Table 2, the informants' age is between 22 and 36 years, with the informants' latest educational background vary from senior high school to undergraduate. Many informants work as private employees; one informant is a housewife, and one informant is a civil servant. Meanwhile, three informants had a cesarean section, and two informants had normal births.

Table 2: Characteristics of postpartum mothers

\begin{tabular}{lllll}
\hline No. & Type of labor & Age & Last education & Profession \\
\hline 1 & Normal & 22 & Senior high school & Private employees \\
2 & Cesarean section & 27 & Undergraduate & Housewife \\
3 & Normal & 28 & Senior high school & Private employees \\
4 & Cesarean section & 29 & Undergraduate & Civil servant \\
5 & Cesarean section & 36 & Undergraduate & Private employees \\
\hline
\end{tabular}

\section{Emotional changes felt by the mother}

The processing of interviews conducted with postpartum mothers and husbands showed the relationship between what the husband does in emotional support, information support, and instrument support, which is helpful or plays a role in the wife's emotional changes.

From Figure 1, the Pearson's correlation coefficient of the emotional influence of the wife from the husband who is processed using Nvivo 12 Plus shows that 0.97 makes the wife more accompaniment,

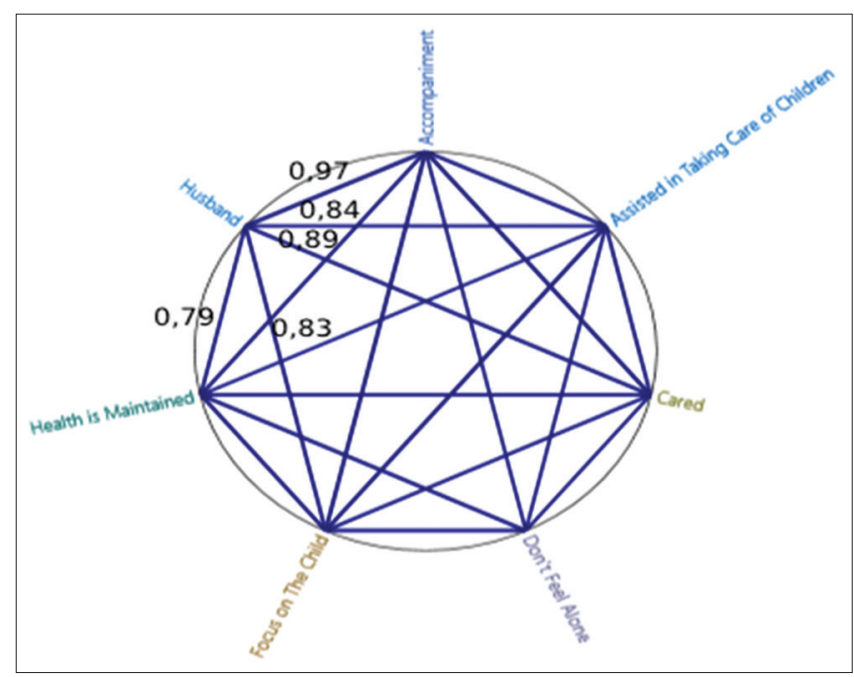

Figure 1: Items clustered by word similarity 
0.84 , the wife feels more helped/the burden is reduced in taking care of household affairs, 0.89 , the wife feels cared for and cared for, 0.83, the wife feels more focused on taking care of the child, and 0.79 , the wife feels that her health is in a faster recovery after giving birth.

The emotional support that a mother receives or feels from her husband, mother, or family positively impacts the clustered above. Mothers who get emotional support feel helpful in taking care of their children, feel that they are not alone, and are more focused on taking care of their children, and maternal health is more awake/health recovery is faster after childbirth.

When researchers asked, "How do you feel after giving birth?" Most of the informants said that they were happy. Apart from positive emotional changes, there are also care, attention, and empathy from husband and family as a safe and peaceful place for rest and recovery and emotional control.

When the informants saw the baby for the $1^{\text {st }}$ time, they were pleased and impatient to immediately care for the baby. Almost all informants only focused on the baby [6]. The findings of existing data indicated that emotional involvement in social relationships created harmonious learning and positive social relationships. Positive emotional and social relationships mean a good or positive relationship between one individual and another. Social support, especially from companions, will provide emotional stability, physical, and psychological comfort for postpartum mothers. Through this support, postpartum mothers will feel loved, cared for, and valued by others. This research is also supported by urban, who needs to support those around them [7]. Women who get social support will undoubtedly be more confident and ready to undergo postpartum with their husbands and families' attention.

\section{Baby care}

One example of caring for babies involves how to bathe the baby until the umbilical cord falls off and soothes the baby when crying. Postnatal caregivers generally take care of the newborns and teach the mother to care for the baby later independently. In this case, most informants, from generation to generation, also passed on from mother to daughter. The informant's analysis results, which were carried out on the 5-8 day postpartum mothers, found that most informants focused on caring for their babies, starting from fulfilling nutrition for breast milk, and healing postpartum wounds. It is in line with the research of Duncan (2010) that on days 3-10, postpartum mothers began to show focused satisfaction with their babies, became interested in caring for their babies, were open to receiving health care and education for themselves and their babies, and it was also easy to encourage them to treat the baby [8].

\section{Wound care}

From the available data, wound care is included in the support received by postpartum mothers. Various interview quotes reveal that some suggestions given by husbands, family friends (mothers), and siblings can accelerate the healing of postpartum wounds and surgical wounds. The advice given includes explaining foods and drinks that can accelerate wound healing, such as eating snakehead fish and herbal drinks, reminding them to clean wounds, reminding themselves to abstain from sexual intercourse for a while. Based on this study, postpartum cesarean section and normal postpartum mothers could not take care of their babies because they still did not have psychological adaptation in postpartum primigravida (taking-hold phase) cesarean section and normal partus in caring for babies [9]. According to Haque (2015), support from husbands and families who know postpartum mothers could bring changes in overcoming the still high number of psychological disorders in postpartum mothers [10].

\section{Nutrition fulfillment}

When asked, "What is the role of your family in your physical recovery after maternity?" The majority of postpartum mothers answered that they were reminded and prepared to take medication, eat vegetables, and to breastfeed the baby.

Fulfillment of nutrition carried out by the family for new mothers, among others, was to provide balanced food and drink to fulfill the nutrition of postpartum mothers so that the cesarean section would dry out quickly. Many of all, informants received proper nutrition for fulfilling balanced nutrition. Following the research conducted by Susilawati (2013), wives felt more secure and comfortable and recovered quickly with their husbands' full support [11].

\section{Conclusion}

Husband's support in the postpartum mother's taking-hold phase primigravida C-section and normal delivery showed that, in this phase, postpartum mothers had good husband support in the psychological adaptation changes. Most mothers, both postpartum mothers, experienced positive emotional changes related to being mothers and excited with their children. They were happy to see their child for the $1^{\text {st }}$ time and wanted to touch and hold even though they still felt confused about caring for their baby independently due to no experience.

Husbands' support helped their wives enjoy receiving health education to care for their babies properly and to meet proper nutrition so that postpartum 
wounds dry out quickly. Baby care and fulfillment of nutrition for postpartum mothers are maternal care so that the support of husbands does help nurses in maternal care for postpartum mothers. Maternal care can involve husbands and their immediate family in helping postpartum mothers for psychological adaptation.

\section{Acknowledgments}

The author would like to thank the Master of Nursing at Universitas Muhammadiyah Yogyakarta to support its publication. This article is a scientific publication in International Conference on Sustainable Innovation (ICOSI) ICoNurs Focal Conference (International Conference on Nursing).

\section{References}

1. Zainur RZ, Loh KY. Postpartum mordibity what we can do. Med J Malays. 2006;61(5):651-6. PMid:17623974

2. Marliandiani Y, Ningrum NP. Buku Ajar Asuhan Kebidanan Pada Masa Nifas Dan Menyusui. Salemba Medika; 2015.
3. Girsang BM. Pengobatan Perilaku Kognitif untuk Depresi Postpartum. J Kesehat Masy Nas. 2013;1(1): 9-12. https://doi. org/10.21109/kesmas.v8i1.335

4. Lewis S, Lee A, Simkhada P. The role of husbands in maternal health and safe childbirth in rural Nepal: A qualitative study. BMC Pregnancy Childbirth. 2015;15(1):162. https://doi.org/10.1186/ s12884-015-0599-8

PMid:26239123

5. Creswell JW. Penelitian Kualitatif and Desain Riset. Indonesia: Pustaka Pelajar; 2014

6. Hodgkinson EL, Smith DM, Wittkowski A. Women's experiences of their pregnancy and postpartum body image: A systematic review and meta-synthesis. BMC Pregnancy Childbirth. 2014;14(1):330. https://doi.org/10.1186/1471-2393-14-330 PMid:25248649

7. Urbayatun S. Social support and post-partum depression tendency in primipara women in the Bantul earthquake area. Humanitas. 2012;7(2):114-22.

8. Duncan G, Baumle W, White LE. Foundations of Maternal and Pediatric Nursing; 2010. Available from: http://www.foundationsof-maternal-pediatric-nursing-3e-white/9781428317765PF. [Last accessed on 2020 Sep 03].

9. Maryunani A. Asuhan Ibu Nifas \& Asuhan Ibu Menyusui. Sulawesi: In Media, 2015.

10. Haque A, Namavar A, Breene A. Prevalence and risk factors of postpartum depression in middle eastern/arab women. Muslim Ment Health. 2015;9(1):20. https://doi.org/10.3998/ jmmh.10381607.0009.104

11. Diani LP,Susilawati LK. The effect of husband's support on wives experiencing anxiety in the third trimester of pregnancy in Gianyar regency. J Psikol Udayana. 2013;1(1):1-11. https://doi. org/10.24843/jpu.2013.v01.i01.p01 